\title{
AHMAD LUTFI FATHULLAH DAN DIGITALISASI ḤAIĪTH DI NUSANTARA
}

\author{
Rahmatullah \\ Universitas Islam Negeri Sunan Kalijaga Yogyakarta, Indonesia \\ E-mail: rahmattullah2508@gmail.com
}

\begin{abstract}
This article aims to discuss the relationship between Ahmad Lutfi Fathullah and digitalization of hadith in Indonesia. The emergence of digitalization of hadith in Indonesia can be associated with one of the leading scholars in the field of hadìth, namely Ahmad Lutfi Fathullah through the Center of Hadith Studies (PKH). The reason for the efforts of hadith digitalization by Ahmad Lutfi Fathullah departed from the awareness to maintain the existence of hadith studies in modern era that demands the use of technological tools. The effort to digitalize the hadith as the result of collaboration with the use of technology has now given birth to a variety of digital hadīth products, such as softwares, websites, android applications and hadìth visualization. The effort to digitalize the hadīth, one of which is undertaken by Ahmad Lutfi Fathullah at this time, has made the tradition of hadith studies especially in Indonesia experience a dynamic orientation and transformation of hadīth studies.
\end{abstract}

Keywords: Hadīth; digitalization; Ahmad Lutfi Fathullah.

\section{Pendahuluan}

Dewasa ini, teks hadìth Nabi mengalami perkembangan model seiring dengan masuknya era digital. Suryadilaga menyatakan bahwa perkembangan teknologi di masa sekarang telah memberikan dampak terhadap produktivitas hadīth. Hadīth kini telah menyentuh ruang digital, yang bisa dilihat di antaranya dengan beredarnya buku atau tulisan tentang hadith yang diterbitkan baik dalam versi PDF (Portable Document Format), software, situs web (website), audio visual, ataupun versi digital lainnya yang bertebaran 
di duni maya. ${ }^{1}$ Fenomena digitalisasi hadīth ini kemudian menarik perhatian para peneliti hadìth, seperti Amran Abdul Halim et al., yang kemudian melakukan penelitian atas aplikasi-aplikasi hadīth yang populer digunakan di Malaysia; ${ }^{2}$ Amna Basharat et al. yang meneliti penggunaan link hadith pada sebuah aplikasi; ${ }^{3}$ dan kemudian Emha Taufiq Lutfi et al. dengan penelitannya atas otentisitas hadīth digital. ${ }^{4}$ Beberapa hasil kajian tersebut setidaknya memberikan gambaran bahwa kini studi hadīth telah mengalami kebaruan orientasi kajian yang ditandai dengan mulai bermunculannya ḥadìth-ḥadìth digital.

Kebaruan orientasi kajian hadìth di era digital merupakan salah satu fase perkembangan yang tidak bisa dilepaskan dari rentetan panjang fase sebelumnya. Meskipun kajian hadīth di tanah air terbilang sudah sangat tua, yaitu sejak masuknya Islam ke Indonesia, fase-fase perkembangannya terbilang sedikit tertinggal jika dibandingkan dengan bidang kajian Islam lainnya di Indonesia. ${ }^{5}$ Bahkan, perkembangan dalam hal digitalisasi pun, yang diketahui sangat masif saat ini, masih terbilang tertinggal jauh dari upaya digitalisasi al-Qur'ān yang sudah terlebih dahulu 'mapan'. Kondisi tersebut, menurut Ummah, dikarenakan hadīth mempunyai karakteristik tersendiri dan kuantitas yang berbeda jika dibandingkan dengan al-Qur'ān. ${ }^{6}$

Digitalisasi hadīth kini merupakan salah satu upaya mengejar ketertinggalan dalam fase perkembangan tersebut, selain sebagai tuntutan zaman digital yang tak terhindarkan. Sebagian kalangan

\footnotetext{
${ }^{1}$ Muhammad Alfatih Suryadilaga, "Kajian Hadis di Era Global", Esensia: Jurnal Ilmu-ilmu Ushuluddin, Vol. 15, No. 2 (2014), 202-203.

2 Amran Abdul Halim et al., "Popularity of Digital Hadith Application (DHA) in Malaysia", International Journal of Civil Engineering and Technology, Vol. 9 (2018), 1382-1390.

3 Amna Basharat et al., "Semantic Hadith: Leveraging Linked Data Opportunities for Islamic Knowledge”, makalah pada konferensi Linked Data on the Web (LDOW), Montreal, Kanada (2016).

${ }^{4}$ Emha Luthfi et al., "Digital hadith authentication: A literature review and analysis", Journal of Theoretical and Applied Information Technology, Vol. 96, No. 15 (2018), 5054-5068.

${ }^{5}$ Muhajirin, "Melacak Akar Pembelajaran Hadis di Nusantara", Holistic Al-Hadis: Jurnal Studi Hadis, Keindonesiaan, dan Integarasi Keilmuan, Vol. 1, No. 1 (2015), 124.

6 Siti Syamsiyatul Ummah, "Digitalisasi Hadis (Studi Hadis di Era Digital)", Diroyah: Jurnal Ilmu Hadis, Vol. 4, No. 1 (2019), 2.
} 
umat Islam terpicu untuk mengembangkan kajian hadīth dengan melakukan upaya rebuilding (membangun kembali) menjadi sesuatu yang lebih menarik serta sesuai dengan spirit era digital yang sedang berlangsung melalui upaya digitalisasi hadīth. ${ }^{7}$ Sekilas dinamika perkembangan kajian hadīth tersebut menjadi sesuatu yang menarik dan penting untuk dikaji lebih jauh lagi. Oleh karena itu, artikel ini akan mengkaji perjalanan digitalisasi hadìth yang kemunculan dan keberadaannya diperankan atau diupayakan oleh salah satu cendekiawan hadīth di Indonesia, Ahmad Lutfi Fathullah. Artikel ini menemukan bahwa digitalisasi hadīth merupakan sesuatu yang urgen dan niscaya dilakukan, dan mempengaruhi orientasi kajian hadīth era kontemporer. Ahmad Lutfi Fathullah, dengan gagasan-gagasan besarnya, menjadi salah satu tokoh penting dalam proyek digitalisasi hadīth di Indonesia.

\section{Kemunculan Digitalisasi Hadīth di Indonesia}

Digitalisasi menurut Kamus Besar Bahasa Indonesia (KBBI) adalah proses pemberian atau pemakaian sistem digital. Digitalisasi yang identik dengan kecanggihan teknologi pada dasarnya lahir untuk memenuhi kebutuhan hidup manusia. Tekologi digital memberikan kemudahan bagi manusia dalam mengakses informasi secara bebas dengan ragam cara dan fasilitas. ${ }^{8}$ Dalam konteks digitalisasi hadīth, secara sederhana dapat diambil pengertian sebagai sebuah proses konversi atau perubahan bentuk kemasan, pemakaian, atau kajian hadìth dengan menggunakan sistem digital.

Kemudahan dan kebebasan dalam mengakses atau mengkaji hadìth sudah bukan sesuatu yang sulit lagi mengingat sudah banyaknya produk hadīth di era new media ini yang bermunculan. Produk hadìth tersebut muncul dengan beragam model dan bertebaran di dunia maya sebagaimana telah dikemukakan oleh Suryadilaga. ${ }^{9}$ Kemunculan beragam produk hadìth di era digital ini tidak bisa dilepaskan dari upaya para ilmuwan hadīth yang berusaha secara terus-menerus untuk menjadikan kajian hadīth

\footnotetext{
7 Luthfi Maulana, "Periodesasi Perkembangan Studi Hadits (Dari Tradisi Lisan/Tulisan hingga Berbasis Digital)", Esensia: Jurnal Ilmu-Ilmu Ushuluddin, Vol. 17, No. 1 (2016), 120.

8 Wawan Setiawan, "Era Digital dan Tantangannya", makalah pada Seminar Pendidikan Nasional, Universitas Pendidikan Indonesia (2017), 1-2.

${ }^{9}$ Suryadilaga, "Kajian Hadis Di Era Global", 202-209.
} 
selalu eksis di setiap zaman yang dilaluinya. Maulana menyebutkan bahwa terdapat periode yang cukup panjang dalam alur perjalanan berkembangnya orientasi tradisi kajian hadith yang semula kajiannya bersifat tradisi lisan hingga sekarang telah menyentuh tradisi kajian yang berbasis atau bersifat digital. ${ }^{10}$

Secara historis, kajian hadīth yang kini sudah merambah ke dunia digital memiliki latar belakang alur sejarah yang cukup panjang dan perkembangan yang dinamis. Menurut Suryadilaga, jika diklasifikasikan, perkembangan hadìth terbagi menjadi tujuh fase, yakni (1) fase kelahiran hadīth dan pembentukan masyarakat Islam; (2) fase kodifikasi dan penyeleksian riwayat hadìth; (3) fase penyebaran hadìth ke berbagai wilayah; (4) fase tadwin hadìth yang berlangsung sejak abad ke-2 H; (5) fase penyaringan, pemeliharaan, dan pelengkapan hadīth yang dimulai sejak awal abad ke-3 H; (6) fase pembersihan, penyusunan, penambahan, dan penghimpunan hadīth pada awal abad ke-4 H; (7) fase pensyarahan, penghimpunan, pen-takhrij-an, dan pembahasan hadīth yang berlangsung sejak $656 \mathrm{H}$ hingga sekarang. ${ }^{11}$

Sementara sumber lain seperti Muhammad 'Ajāj al-Khaṭib dalam karyanya al-Sunnah Qabl al-Tadwin (hadīth sebelum dibukukan) menyebutkan bahwa alur perkembangan hadīth terdiri dari 3 fase, yakni pra-pembukuan, masa pembukuan, dan pascapembukuan. ${ }^{12}$ Namun demikian, terlepas dari adanya ikhtilaf dalam pemetaan fase perkembangan studi hadīth, kini mesti disepakati bahwa berdasarkan sisi historisitasnya tersebut, terdapat pelajaran yang dapat dipetik tentang betapa tingginya perhatian dan semangat kalangan umat Islam kala itu dalam berupaya untuk memelihara dan mengkaji hadīth nabi. Buah dari perhatian dan semangat itu pun nyatanya dapat dirasakan umat Islam pada saat ini yang dibuktikan dengan bertebarannya literatur hadīth dan beragamnya model kajian hadìth yang masih tetap eksis dan dapat dinikmati oleh setiap kalangan di masa sekarang.

Eksistensi itu masih terus berlanjut hingga masa sekarang. Hal ini terlihat dari adanya upaya digitalisasi terhadap hadīth nabi

\footnotetext{
${ }^{10}$ Maulana, "Periodesasi Perkembangan Studi Hadits".

11 Suryadilaga, "Kajian Hadis di Era Global", 200-201.

12 Muhammad 'Ajaj al-Khațīb, al-Sunnah Qabl al-Tadwinn (Beirut: Dār al-Fikr, 1981).
} 
dalam berbagai macam aspeknya. Kondisi ini, menurut hemat penulis, bisa disebut "new era" atau babak baru dalam pemeliharaan atau pengkajian hadìth nabi. Perkembangan hadīth yang kurang begitu signifikan di masa sebelumnya telah memantik kalangan intelektual hadīth untuk melakukan rebuilding menjadi sesuatu yang lebih menarik, kekinian, dan berkesesuaian dengan spirit era digital. Hasil dari digitalisasi tersebut di antaranya adalah software-softwar hadīth seperti: Maktabah Syamilah, al-Jami" al-Hadith al-Nabawi, Jawāmi al-Kalim, dan Maktabah Alfiyah li al-Sunnah al-Nabawiyah. Kemunculan beberapa software tersebut kemudian membuka jalan bagi produk-produk digital hadīth yang lain untuk turut muncul dengan beragam bentuk dan model, seiring semakin berkembangnnya teknologi dan media.

\section{Ragam dan Bentuk Digitalisasi Hadīth ${ }^{13}$}

1. Programisasi dan Literatur

Salah satu pemrograman digital hadìth bisa dilihat pada sebuah situs web (website), yaitu program komputer yang befungsi sebagai penyedia layanan akses kepada beberapa laman; atau sebuah situs yang berisikan beragam informasi yang disediakan oleh pihakpihak tertentu. Dengan demikian, situs web hadīth dapat dipahami sebagai sebuah situs web yang di dalamnya menyediakan fasilitas guna mengkaji hadìth nabi. Terdapat beberapa situs web jenis ini, di antaranya adalah Islamweb.net, Carilahhadis.com, Dorar.net, termasuk literatur versi digital.

Islamweb.net merupakan situs yang dikelola dari Doha, Qatar, yang memuat berbagai macam kajian keislaman dan juga memuat beberapa aplikasi yang dapat dinikmati secara online maupun offline. Salah satu aplikasi tersebut dapat digunakan untuk mengkaji hạaīth khususnya terkait aktivitas takhrij hadīth. Bagi orang yang ingin

13 Dalam identifikasi awal, setidaknya terdapat beberapa bentuk model hadīth yang bisa dilacak jejak digitalnya; pertama, digitalisasi literatur dan programisasi, yaitu dengan melakukan proses scan terhadap literatur hadìth lalu mengunggahnya ke media sosial, atau dengan membuat programming hadīth berupa software atau aplikasi-aplikasi hadīth yang bisa diakses di internet atau diunduh lalu diinstal pada masing-masing perangkat lunak yang dimiliki pengguna. Kedua, berupa video sebagai bentuk audioisasi dan visualisasi hadīth. Ketiga, meme atau gambar sebagai bentuk visualisasi hadīth. Miski Mudin, Islam Virtual: Diskursus Hadis, Otoritas, dan Dinamika Keberislaman di Media Sosial (Yogyakarta: Bildung, 2019), 69. 
memanfaatkan situs ini, ada baiknya memiliki pengetahuan bahasa asing, sebab situs ini hanya menyediakan lima pilihan bahasa, yakni bahasa Ingris, Prancis, Jerman, Spanyol, dan Arab. Berikut ini tampilan situs Islamweb.net dan aplikasi hạaīth yang disediakan:

\section{Gambar 1:}

\section{Tampilan Situs Islamweb.net}

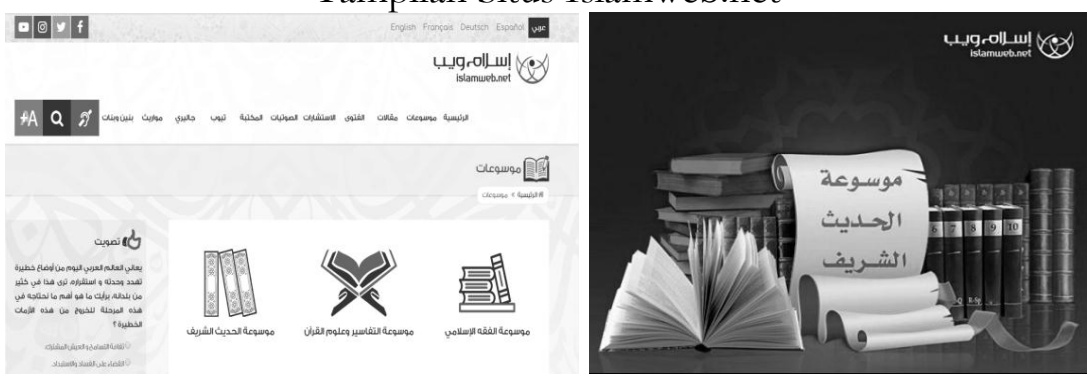

Sementara Carilahhadis.com merupakan situs sederhana yang dapat digunakan untuk mencari hadīth secara tematik. Cara mengaplikasikannya adalah dengan menuliskan kata kunci topik hadìth yang ingin dicari. Situs ini hanya menyediakan 55 literatur kitab hadìth, di mana para pengguna dapat dengan bebas memilih kitab mana saja yang ingin dijadikan rujukan dalam pencarian hadìth yang dimaksud. Menurut hemat penulis, kelebihan dari situs ini adalah pemberian harakat pada hadīth yang ditampilkan, baik pada bagian sanad maupun matan. Namun demikian, berdasarkan temuan penulis saat menggunakan situs ini, kelebihan tersebut tidak berlaku untuk semua hadīth, melainkan hanya beberapa saja. Adapun kekurangan dari situs ini adalah tidak adanya keterangan atua informasi terkait status suatu hadīth.

\section{Gambar 2:}

Tampilan Situs Carilahhadis.com
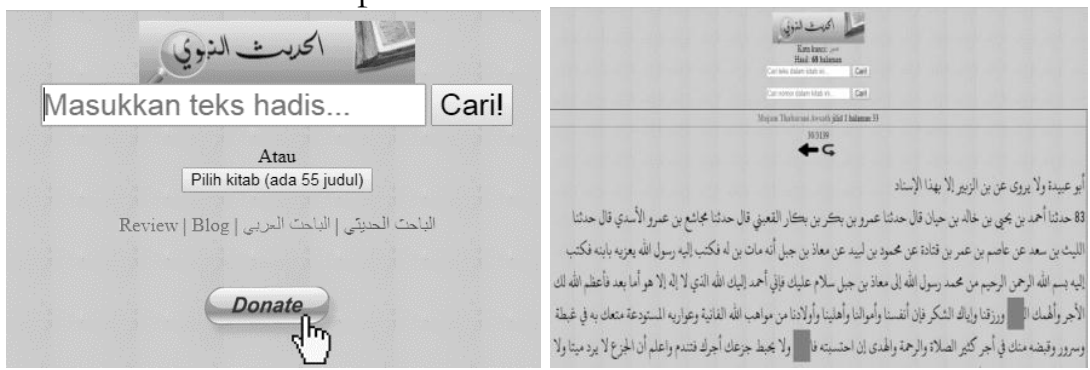

Selanjutnya, Dorar.net merupakan salah satu situs berbahasa Arab yang menyediakan fasilitas kajian hadīth. Kata "dorar" sendiri 
merupakan singkatan dari al-Durar al-Sanijah, sebuah lembaga yang didedikasikan untuk pelestarin hadīth nabi melalui basis data elektronik modern. Perlu untuk diketahui bahwa situs ini tidak dikhususkan untuk hanya memuat hadīth, tetapi juga memberikan ruang pada kajian-kajian keislaman lainnya. Fasilitas yang disediakan oleh situs ini berupa pengayaan fitur yang bisa digunakan untuk mengkaji hal-hal yang terkait dengan hadìth nabi, seperti pelacakan perawi dari kalangan kodifikator hadìth, kualitas hadìth, dan keterangan keberadaan hadīth dalam suatu kitab hadīth (dilengkapi jilid dan halaman). Selain itu, situs ini juga menyediakan fitur yang memungkinkan penggunanya untuk memodifikasi kriteria hadìth yang diinginkan, misalnya hạadìth sahih saja, hạadìth lemah sajam dan seterusnya. ${ }^{14}$ Situs ini beroperasi online, sehingga pemanfaatan situs ini mensyaratkan adanya koneksi internet yang stabil.

\section{Gambar 3:}

Tampilan Situs Dorar.net

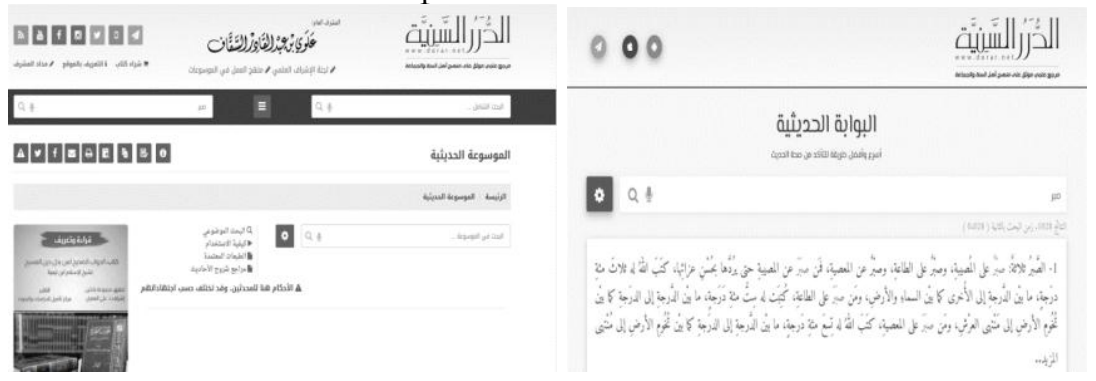

Tidak hanya dalam bentuk situs web, wujud digitalisasi hadīth lainnya dapat dijumpai dalam banyak bentuk dan model, termasuk dalam bentuk literatur versi digital. Di antara bentuk dan model literatur versi digital adalah format PDF atau dokumen sehingga penggunaannya bersifat praktis atau tidak perlu adanya proses instalasi terlebih dahulu setelah proses pengunduhan. Pengguna cukup membuka dokumen digital tersebut di perangkat lunak yang tersedia seperti telepon seluler, laptop, atau perangkat lainnya yang mendukung untuk digunakan dalam megakses dokumen digital tersebut. Dalam konteks ini, terlihat adanya pergeseran wujud literatur hadīth yang asalnya benbentuk fisik (bardware) kemudian berubah menjadi versi digital (software) lewat proses scanning.

${ }^{14}$ Ibid., 75. 
Terhadap literatur versi kitab hadīth yang telah melalui proses scaning biasanya disebut dengan istilah e-book (electronic book), yang wujud digitalnya sama persis dengan kitab aslinya. ${ }^{15}$

Literatur hạaīth lainnya juga dapat dilihat dalam bentuk tulisantulisan hasil kajian akademik hadīth dalam berbagai perspektif yang telah disubmit dan diterbitkan oleh berbagai situs jurnal akademik.

2. Visualisasi Hadīth

Menurut KBBI, "visualisasi" memiliki dua pengertian. Pertama, pengungkapan gagasan atau perasaan dengan menggunakan bentuk gambar, tulisan (huruf/kata dan angka), peta grafik, dan sebagainya. Kedua, proses pengubahan konsep menjadi gambar untuk disajikan lewat televisi oleh produsen. Sedangkan pengertian sederhananya adalah seperti apa yang dikemukakan oleh Mudin, yakni suatu media yang melibatkan penglihatan karena berbentuk gambar dan sejenisnya. ${ }^{16}$ Selanjutnya, pada bagian ini akan diuraikan beberapa bentuk visualisasi hadīth berupa audiovisual dan visualisasi hạaīth dalam bentuk gambar atau meme dan komik.

Hadīth dalam bentuk audiovisual berarti suatu hadith berada pada ruang media yang memuat suara dan gambar sekaligus, yang biasanya juga melibatkan gerak dan juga pencahayaan yang cukup. Dengan menggunakan format ini, hadīth dapat menciptakan daya tarik lebih bagi para audiensnya, khususnya penikmat media sosial. Hal ini bisa dimaklumi, karena melalui format audiovisual, kemasan hadith berubah menjadi sesuatu yang menarik serta lebih mudah untuk dipahami. Selain itu, dengan format ini, hadīth menjadi sesuatu yang unik karena wujud interpretasinya terkadang dapat melahirkan dhawq (rasa) tersendiri bagi para penikmatnya sebagai efek visualisasi tersebut. ${ }^{17}$

Audiovisual hadīth setidaknya dapat dijumpai dalam empat model; (1) ceramah atau kegitan kajian hadìth lainnya yang bersifat offline (nyata) yang dilakukan oleh para kalangan tertentu yang kemudian diunggah atau disiarkan ke berbagai media sosial (maya) secara langsung (live); (2) hanya sebatas menampilkan redaksi hadìth tanpa adanya efek visualisasi; (3) hạadìth yang ditampilkan

\footnotetext{
${ }^{15}$ Ibid., 73-74.

${ }^{16}$ Ibid., 79.

17 Ibid.
} 
dalam bentuk narasi dan menggunakan media audiovisual; ${ }^{18}$ dan (4) hadìth yang ditampilkan dalam bentuk animasi, yang hal ini bisa dikatakan sebagai salah satu gaya living badith (hadith yang hidup). Contoh keempat model tersebut bisa dilihat pada gambar-gambar berikut:

Gambar 4:

Audiovisual Hadīth Bentuk Pertama

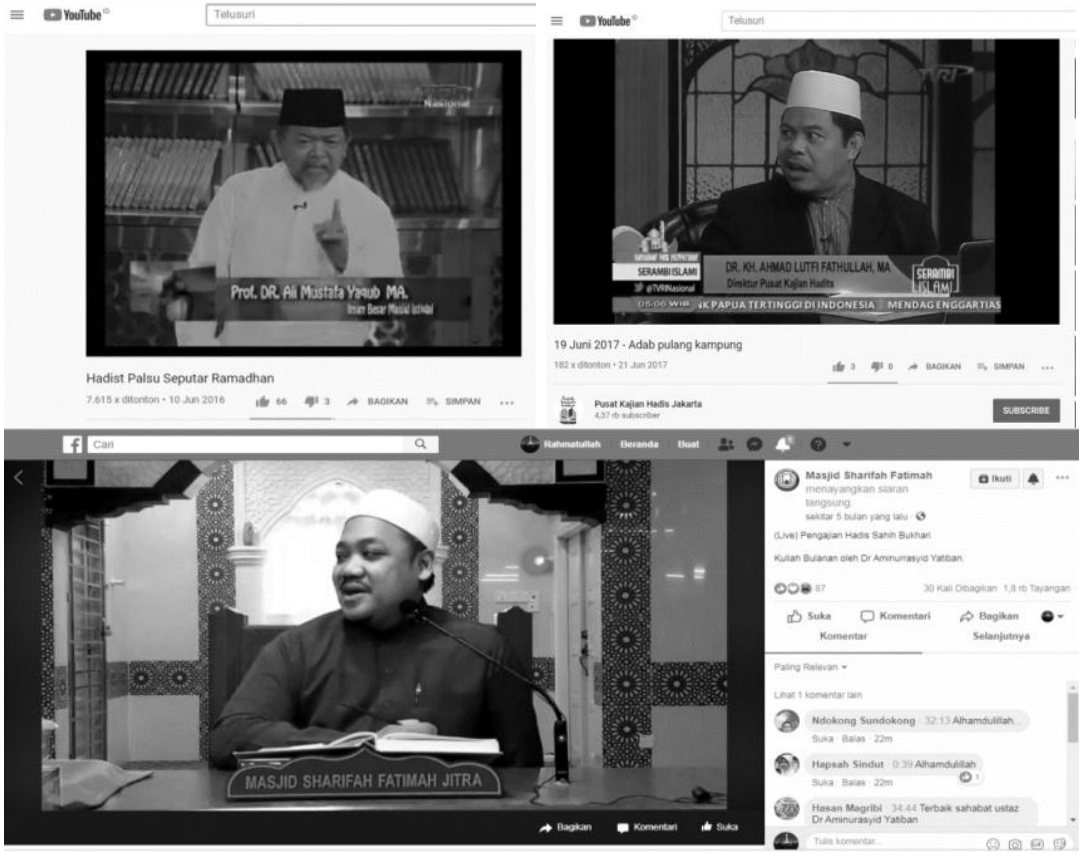

Gambar 5:

Audiovisual Hadìth Bentuk Kedua

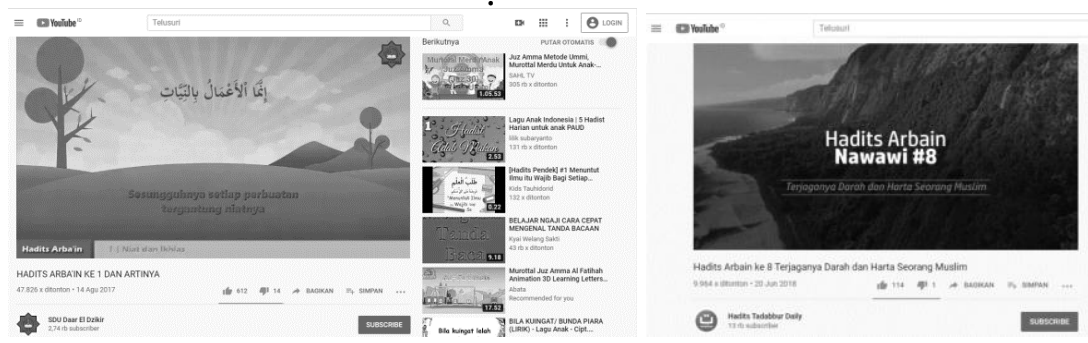

${ }^{18}$ Ibid., 80. 
Gambar 6:

Audiovisual Hadīth Bentuk Ketiga

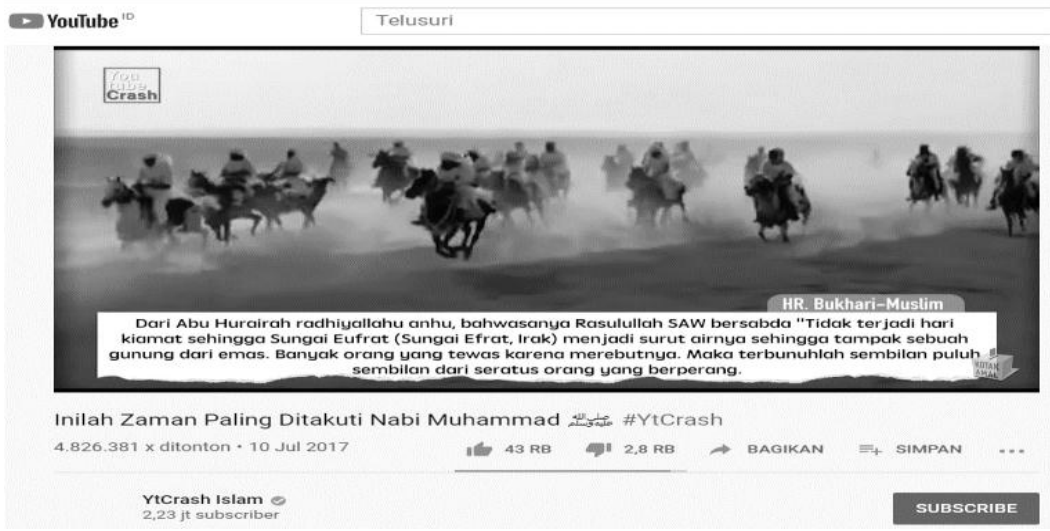

Gambar 7:

Audiovisual Hadīth Bentuk Keempat

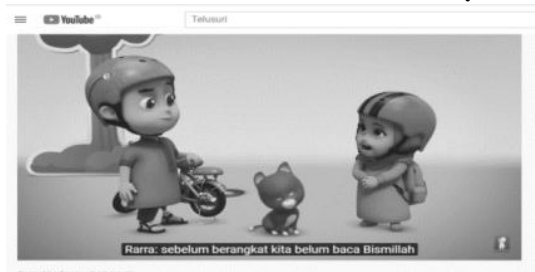

NUSBA DAHESTATNYA BASMMLAH

B : $=-\infty$ ons

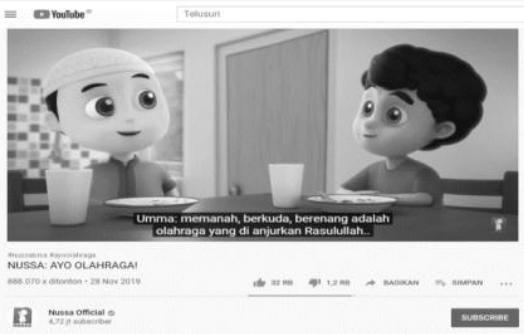

B

Video animasi yang berjudul "NUSSA: Dahsyatnya Basmallah" merupakan bentuk interpretasi dari pemahaman hadith nabi yang redaksinya sebagai berikut:

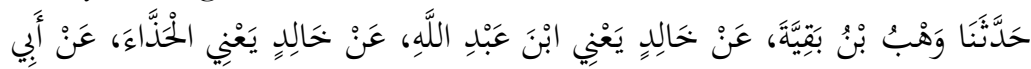

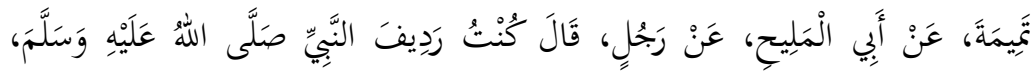

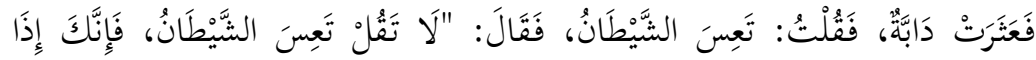

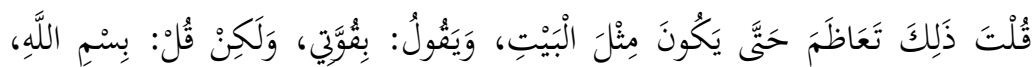

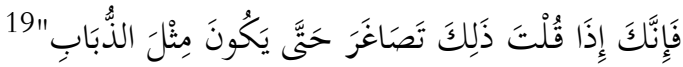

${ }^{19}$ Lihat hadīth No. 4982 pada bab jangan berkata buruk terhadap diri sendiri. Hadīth ini dihukumi sahih oleh al-Banī. Sulaymān b. al-Asy'as b. Ishāa b. Bishr b. Shidād b. Amr al-Azdī al-Sijistānī, Sunan Abì Dāwūd, Vol. 4, Tahquịq: Muḥammad Muḥy al-Dīn 'Abd al-Ḥamīd (Beirut: Maktabah al-'Aṣrīyah, t.th.), 296. 
"Ketika aku dibonceng nabi, tiba-tiba unta beliau tergelincir. Serta merta aku mengatakan, 'celakalah setan'. Maka beliau bersabda: 'Jangan kamu katakan 'celakalah setan', sebab jika kamu katakan seperti itu maka setan akan membesar sebesar rumah dan dengan sombongnya setan akan berkata, 'itu terjadi karena kekuatanku'. Akan tetapi, ucapkanlah 'Bismillāh', sebab jika engkau mengucapkan bism Allāh, niscaya setan akan mengecil hingga seukuran lalat"” (HR. Abū Dāwūd).

Sedangkan untuk animasi yang berjudul "AYO OLAHRAGA" dibuat dengan berlandaskan potongan hadīth yang redaksinya sebagai berikut:

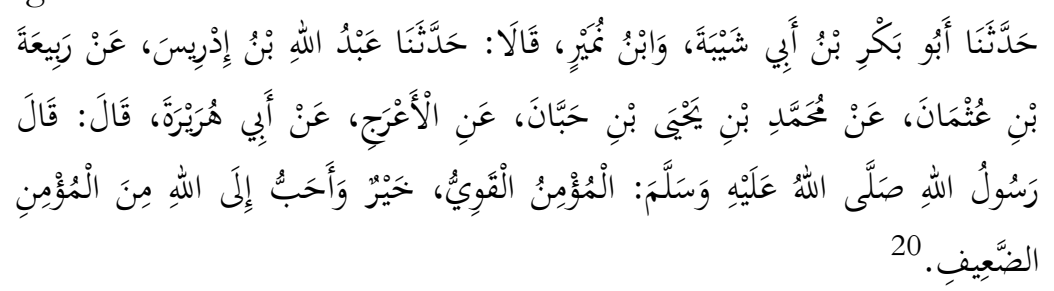

"Dari Abū Hurayrah berkata, bahwasanya Rasulullah bersabda: 'Seorang mukmin yang kuat, lebih baik dan lebih dicintai Allah daripada seorang mukmin yang lemah"' (HR. Muslim).

Menurut hemat penulis, bentuk keempat ini merupakan bentuk yang unik dan sangat menarik, karena hadìth dapat direpresentasikan atau divisualkan melalui animasi yang tentu dapat menciptakan daya tarik bagi anak-anak untuk menyaksikannya. Hal ini merupakan sesuatu yang positif, karena lewat media ini hadīth dapat diajarkan ke anak-anak sedini mungkin tanpa membuat mereka bosan atau setidaknya kemungkinannya penolakan mereka terhadap pelajaran hạīith tersebut sangatlah kecil.

Berbeda dari bentuk audiovisual di atas adalah visualisasi hadīth dalam bentuk gambar atau meme dan komik. Maksud dari visualisasi hadīth dalam bentuk gambar atau meme yakni bagaimana sebuah hadīth dinarasikan ke dalam bentuk suatu gambar yang dinilai relevan dengan kandungan atau konten hadīth. Dalam hal ini terdapat dua ragam konten visualisasi. Yang pertama adalah konten hadīth dan gambar, yang dibuat dengan cara

${ }^{20}$ Lihat hạāìth No. 2664 pada Abū Hasan Muslim b. al-Hujjāj al-Qushayrī alNayshābūrī, Saḥ̄ḥ Muslim, Vol. 4, tahqīq oleh Muhammad Fu'ād 'Abd al-Bāqī (Beirut: Dār al-Iḥyā’ al-Turāth al-'Arabī, t.th.), 2052. 
menggabungkan keduanya, ${ }^{21}$ sehingga menghasilkan sebuah gambar dengan tambahan caption tertentu. Dalam istilah saat ini, ia disebut dengan meme. ${ }^{22}$ Contohnya sebagai berikut:

Gambar 8:

Visualisasi Hadīth dalam Bentuk Meme

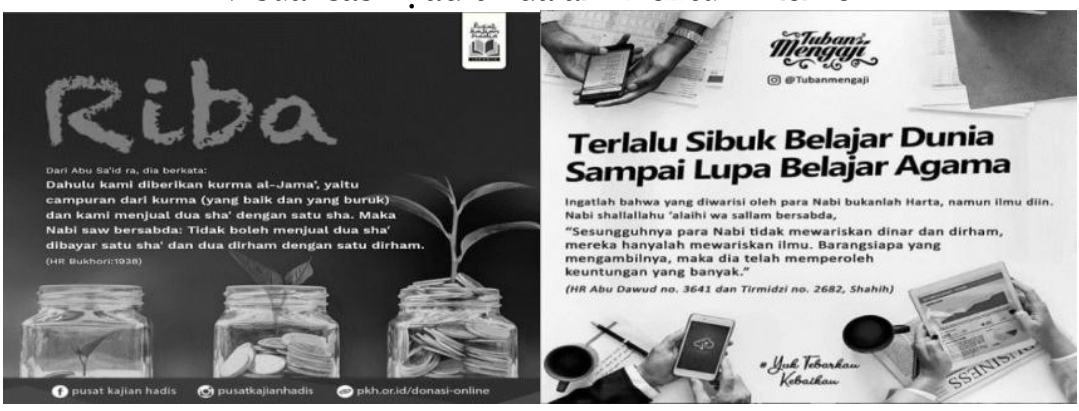

Kemudian visualisasi hadīth tersebut juga dapat dilihat dalam bentuk komik hadīth, sebagai berikut:

Gambar 9:

Visualisasi Hadīth dalam Bentuk Komik

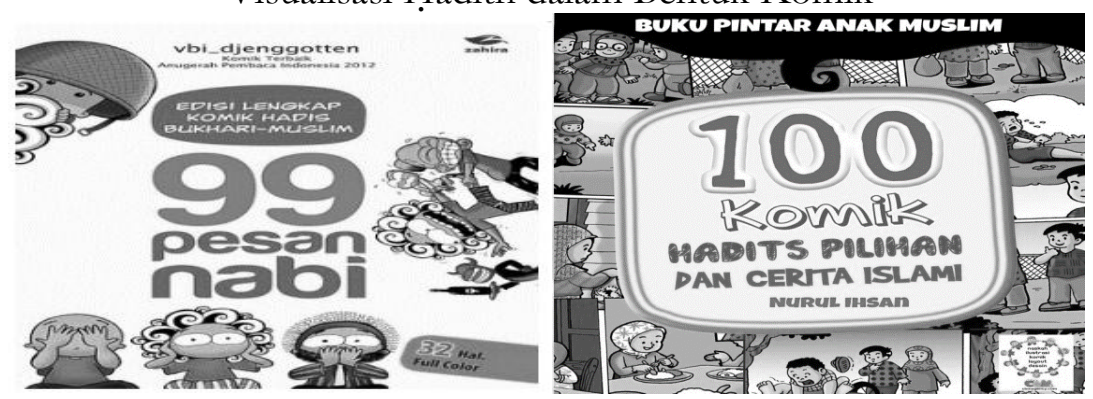

\section{Urgensi Digitalisasi Hadīth}

Salah satu dampak terpenting era new media saat ini adalah terjadinya pergeseran otoritas keagamaan; yang semula merujuk pada pelbagai otoritas yang eksistensinya bersifat riil (nyata) dan tradisional, kini bergeser pada otoritas yang berwujud lebih modern atau yang keberadaanya dapat ditemukan dalam suatu media digital. Dampak tersebut dapat dilihat terutama di kalangan generasi milenial, di mana media memiliki peran sentral dalam proses transformasi pengetahuan. Para generasi milenial lebih

21 Mujibur Rahman, "Visualisasi Agama di Ruang Publik: Komodifikasi, Reproduksi Simbol dan Maknanya", Humanistika: Jurnal Keislaman, Vol. 4, No. 1 (2018), 96.

${ }^{22}$ Mudin, Islam Virtual, 83. 
tertarik belajar agama melalui media digital ketimbang melalui media-media tradisional. ${ }^{23}$ Kondisi tersebut setidaknya menjadi alasan penting atas perlunya upaya digitalisasi kajian keislaman, dalam hal ini kajian hadīth, selain mengejar ketertinggalan dari pada kajian keislamana lainnya yang telah terlebih dahulu semakin 'semarak' di era digital ini.

Demikian pula, dalam konteks dakwah, upaya digitalisasi hadìth juga menemukan titik urgensinya. Dinamika dakwah di era digital menuntut kreativitas dan inovasi guna membuat setiap orang mampir dan mengikuti jalan kebaikan. Dalam strateginya, upaya dakwah haruslah menyesuaikan dengan perkembangan zaman kekinian (mu'assirab/modern) jika tidak ingin ditinggalkan peminatnya. ${ }^{24}$ Tentu, hal ini bisa dijawab dengan cara, salah satunya, melakukan upaya pengajaran atau pengkajian bidangbidang keislaman melalui media digital.

Secara umum, dalam banyak kasus kekinian, digitalisasi selalu menjadi pilihan penting guna menarik lebih banyak manfaat, seperti menghemat waktu, proses belajar menjadi lebih cepat, menghemat uang, lebih aman, selalu memperoleh informasi terkini, selalu terhubung, membuat keputusan yang lebih baik, meringankan aktivitas, membuat lebih bahagia, dan dapat mempengaruhi dunia. ${ }^{25}$ Tak terkecuali dalam konteks kajian hadīth, upaya digitalisasi mendapatkan posisinya mengingat begitu kompleksnya kajian hadīth dengan berbagai literaturnya yang teramat banyak dan aktivitas kajiannya yang masih cenderung bersifat tradisional. Oleh karenanya, adalah hal yang amat penting untuk membuat kajian hadīth menjadi lebih menarik, lebih efisien, lebih modern, sehingga lebih mudah untuk meningkatkan gairah para pengkajinya. ${ }^{26}$

\footnotetext{
${ }^{23}$ Ibid., 21.

24 Waryono Abdul Ghafur, "Dakwah Bil-Hikmah di Era Informasi dan Globalisasi: Berdakwah di Masyarakat Baru", Jurnal Ilmu Dakwah, Vol. 34, No. 2 (2014), 256.; Nur Ahmad, "Tantangan Dakwah di Era Teknologi dan Informasi: Formulasi Karakteristik, Popularitas, dan Materi di Jalan Dakwah", Addin, Vol. 8, No. 2 (2014), 331; Wahyu Budiantoro, "Dakwah di Era Digital”, Komunika: Jurnal Dakwah dan Komunikasi, Vol. 11, No. 2 (2018).

${ }_{25}$ Munir, Pembelajaran Digital (Bandung: CV. Alfabeta, 2017), 116-17.

${ }^{26}$ Bagaimana pemanfaatan teknologi dapat berefek positif pada perkembangan minat, motivasi, dan perilaku belajar dalam sebuah proses pembelajaran, dapat ditelusuri lebih jauh dalam Muhasim, "Pengaruh Tehnologi Digital terhadap
} 


\section{Peran Ahmad Lutfi Fathullah dalam Upaya Digitalisasi Hadīth di Indonesia}

Perbincangan mengenai upaya digitalisasi hadìth di Indonesia tidak bisa dilepaskan dari keberadaan salah satu tokoh pentingnya, yakni Ahmad Lutfi Fathullah, seorang akademisi dan juga kiai, yang melakukan digitalisasi hadith lewat sebuah lembaga yang dibangunnya dengan nama Pusat Kajian Hadis (PKH) yang berlokasi di kota Bogor, Jawa Barat. PKH merupakan lembaga yang dibangun dalam rangka ikut menjaga kemurnian ajaran Islam terutama yang bersumber dari hadīth nabi, serta menjadi wadah dan media untuk mengkaji dan menyebarluaskan hadìth-ḥadīth nabi. ${ }^{27}$

Upaya digitalisasi hadīth oleh Fathullah bertujuan untuk memberikan kemudahan bagi masyarakat dalam mengkaji hadīth, sehingga masyarakat dapat dengan mudah menelusuri atau memperoleh referensi-referensi hadith dan mengkajinya secara digital, terkhususnya bagi kalangan akademisi yang menekuni bidang kajian hadìth. Selain itu, upaya tersebut juga merupakan salah satu aktualisasi dari misi PKH dalam menyebarluaskan ilmuilmu yang bersumber dari al-Qur'ān dan hadīth melalui media cetak, elektronik, dan kegiatan pendidikan. Misi ini pun pada kenyataannya kini sudah terealisasi dengan adanya literatur hadìth digital yang sudah tersedia baik pada program komputer, situs web, dan android berkat ketekunan dan komitmen para programmer di $\mathrm{PKH}^{28}$

Lebih lanjut, upaya digitalisasi hadīth yang dilakukan oleh Fathullah merupakan sebuah ide yang muncul dan berangkat dari kesadarannya atas perlunya akses yang mudah dalam memahami atau mempelajari hadīth nabi, sehingga langkah yang coba ia tempuh untuk merealisasikan idenya tersebut adalah dengan

Motivasi Belajar Peserta Didik", Palapa: Jurnal Studi Keislaman dan Ilmu Pendidikan, Vol. 5, No. 2 (2017), 68; lihat pula Shulhan Alfinnas, "Arah Baru Pendidikan Islam di Era Digital", Fikrotuna: Jurnal Pendidikan dan Manajemen Islam, Vol. 7, No. 1 (2018), 816.

27 Lihat https://pkh.or.id., khususnya pada kolom "Tentang PKH”. Diakses pada 5 Desember 2019.

${ }^{28}$ Istianah dan Sri Wahyuningsih, "The Hadith Digitization in Millennial Era: A Study at Center for Hadith Studies, Indonesia”, QIJIS, Vol. 7, No. 1 (2019), 3435. 
membumikan hạdīth melalui media digital. Bagi Fathullah, keberadaan teknologi digital meniscayakan kehadirannya untuk dimanfaatkan di segala aktivitas kehidupan manusia, terlebih dalam hal pengajaran atau penyebaran hadīth nabi. ${ }^{29}$ Oleh karenanya, bisa dimaklumi, jika upaya digitalisasi hadīth dirumuskan menjadi salah satu program utama di lembaga PKH. Hasil dari program ini adalah munculnya beragam bentuk hadìth versi digital yang terwujud baik dalam format software, aplikasi android, dan visualisasi hadìth yang telak banyak dinikmati kini.

\section{Implementasi Ide-ide Ahmad Lutfi Fathullah dalam Digitalisasi Ḥadīth}

Implementasi ide-ide Fathullah secara spesifik dirumuskan dalam bentuk rancangan program kerja $\mathrm{PKH}$ yang terbagi menjadi tiga, yakni program jangka panjang, jangka menengah, dan jangka pendek. ${ }^{30}$ Upaya digitalisasi hadīth yang digagas oleh Fathullah telah dirumuskan ke dalam program jangka pendek yang kini sudah direalisasikan dengan baik dan hasilnya pun sudah dapat dinikmati oleh masyarakat Indonesia. Hasil digitalisasi hadith tersebut antara lain adalah seperti berikut ini.

Pertama, software hadīth. Software hadīth produksi program PKH ini bertujuan untuk memberikan kemudahan terhadap masyarakat dalam mengkaji hadìth. Software-software hadìth ini dapat dinikmati masyarakat secara gratis dengan cara mengunduhnya di laman situs web PKH. Software-software hadith yang telah ada ini pun sering kali digunakan oleh Fathullah dalam aktivitas pengajaran hadìth yang ia lakukan di berbagai tempat. Berdasarkan pengamatan penulis, kegiatan kajian hadìth yang dilakukan Fathullah tersebut dinilai menjadi lebih menarik karena sudah memanfaatkan teknologi. Kajian tersebut, yang sebelumnya dilakukan secara tradisional kini menjadi lebih modern dan memberikan antusiasme tersendiri bagi para audiens yang terlibat dalam kajian tersebut.

Kedua, situs web. PKH memiliki sebuah situs web yang beralamatkan di warungustad.com. Menurut Kinta Minhaji, pada

\footnotetext{
${ }^{29}$ Alfi Nur'aini, "Metodologi Interpretasi Hadis Ahmad Lutfi Fathullah dalam Kajian Kitab Kuning Shahih Bukhari (Studi Terhadap Interpretasi Audio Visual)" (Tesis--UIN Sunan Kalijaga Yogyakarta, 2018), 61.

${ }^{30}$ Lihat https://pkh.or.id/tentang-kami/program-kerja-pkh/. Diakses pada 5 Desember 2019.
} 
"Pengantar" situs ini, disebutkan disebutkan bahwa situs ini muncul dan berangkat dari keresahan Tim PKH terhadap adanya video-video dakwah yang bertebaran yang seringkali bersandingan dengan gambar-gambar yang dinilai kurang layak atau terindikasi gambar yang bersifat kemungkaran. Guna menghindari hal yang demikian itu, maka perlu adanya wadah yang khusus menampung video-video dakwah dimaksud, sekaligus menjadi penyaring atas konten lainnya yang dinilai tidak layak untuk bersanding dengan konten dakwah. Situs ini kemudian mengklasifikasi konten video dakwah tersebut berdasarkan dua kategori besar, yakni dakwah berbahasa Indonesia dan Arab. ${ }^{31}$

Gambar 10:

Tampilan Situs Web Warungustad.com

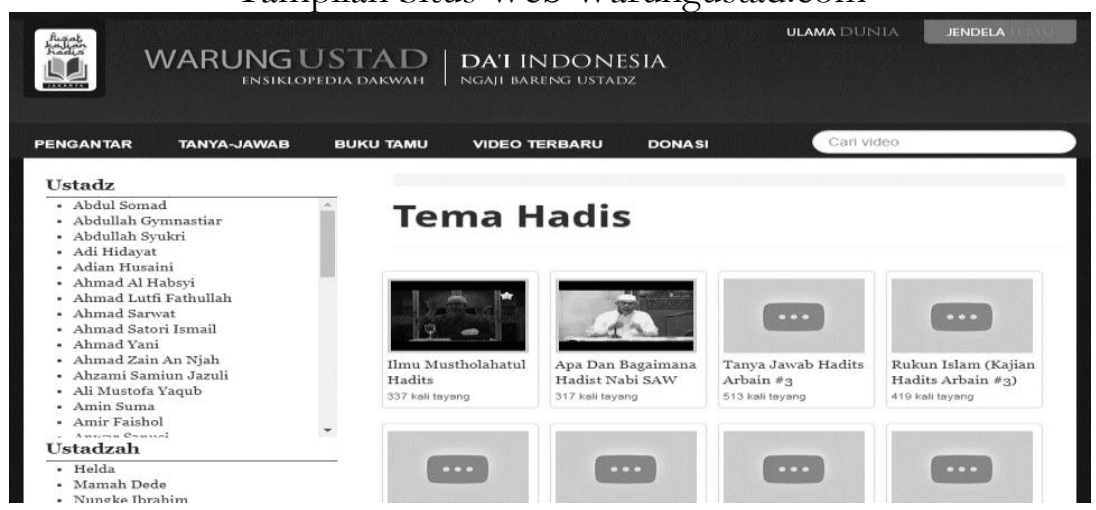

Ketiga, aplikasi android. Aplikasi android ini terbagi menjadi dua ranah produksi, yang pertama yakni aplikasi android yang diproduksi oleh pihak PKH sendiri, dan yang kedua adalah aplikasi android yang diproduksi oleh para mahasiswa magang atau praktik lapangan di PKH. Mahasiswa mendapat bimbingan dan pengawasan langsung dalam proses pembuatan aplikasi android tentang kajian hadīth tersebut. Dalam prosesnya, pihak PKH bertanggung jawab sebatas pada proses digitaliasi hadīthnya. Sedangkan terkait konten hadīth-ḥadìth yang akan didigitalkan tersebut dilimpahkan ke mahasiswa tanpa adanya pengawasan atau pengontrolan lebih lanjut. Daftar produk aplikasi hadīth yang dihasilkan PKH adalah sebagai berikut:

31 Lebih lanjut lihat http://warungustad.com/pengantar/. Diakses pada 5 Desember 2019. 
Adapun daftar produk aplikasi hadīth $\mathrm{PKH}$ adalah sebagai berikut; Hazarta, 40 Kumpulan Ayat Populer, 40 Hadis Mudah Dihafal - Sanad dan Matan (Bukhari), Potret Pribadi Nabi Mubammad, Alquran al-Hadi, Membuka Pintu Rezeki Melalui Wirid Pagi dan Petang, Manasik Haji dan Umrah, Satu Hari Satu Hadith, Qurban: Sejarah, Figh dan Fadbilah, Fatwa dan Tausyiab MUI.

Sementara itu, produk pesantren PKH adalah sebagai berikut; 40 Hadith Dosa Besar yang dianggap Remeh, 40 Hadis Populer Keutamaan Alquran, 20 Hadis Tentang Aqidah, 40 Hadis Muamalah, 40 Hadis Sains, Riyadush Shalihat: Aplikasi Hadis Wanita Salibah, Potret Masa Depan di Masa Nabi, 40 Hadis Qudsi, 40 Hadis Kepedulian Sosial, Pengobatan Ala Nabi, 40 Hadis Gerakan Shalat Secara Sains, 40 Hadis Menyantuni Anak Yatim, 40 Hadis Keutamaan Shalat, 40 Hadis Tentang Ilmu, 40 Hadis Tentang Shalat, 40 Hadis Perumpamaan, 40 Hadis Kewajiban Seorang Istri, 20 Hadis Sains, Ayat-ayat Ekonomi dalam Alquran, Takbrij Hadis Antara Teori dan Praktik, 40 Hadis Etika di Dalam Masjï, 40 Hadis Keajaiban Sedekah, 40 Hadis Tentang Iman, 40 Hadis Tentang Sifat Allah, Anjuran, Nasibat, Hak, dan Kewajiban Perempuan, 40 Hadis Pilihan Terkait Akblak, 20 Hadis tentang Ibadah, Kumpulan Hadis Hari Baik, 40 Hadis tentang Muamalah Perempuan, Kumpulann Hadis tentang Pemimpin, Pembentukan dan Pendidikan Karakter Anak, 40 Hadis tentang Nikah, 40 Hadis Sunnah yang Terabaikan, Larangan Riba dalam Alquran dan Hadis, 40 Hadis Seputar Ramadhan, Shalat Sunnah, Yuk! Hadis Keutamaan Shalat Sunnah, Tafsir Ringkas-Alquran dan Krisis Lingkungan, Perdagangan dalam Alquran, Memaknai Tawakal dalam Alquran, 40 Hadis Toleransi, Mengikat Makna di Jagad Maya, Qisas dan Diyat dalam Islam, Perdamaian yang Kami Pahami, 40 Hadis Tentang Jihad, Menggapai Hidup Berkah, Be Khaiir, Kumpulan Hadis Motivasi Dunia Akbirat, Ilmu Tajwid, Menuju Keluarga Sakinah Mawaddah wa Rahmah, 40 Hadis Tentang Hewan dan Tumbuban, Islam dan Perdamaian, Hadis Wanita Seputar Haid, Pesona Istri yang Sholehah, Hadis Tentang Pendidikan Anak.

Jika ditelisik lebih jauh lagi, hal menarik dari upaya ini adalah bahwa mayoritas karya-karya yang dirilis $\mathrm{PKH}$ cenderung memilih tema 40 Hadith (Hadith Arba'in) dalam rancangan pembuatan aplikasi hadìth-nya. Hal ini tentu menimbulkan pertanyaan tentang mengapa tema yang dipilih adalah Hadith Arbain. Pertanyaan ini setidaknya sudah dijawab oleh $\mathrm{PKH}$ salah satunya lewat aplikasi 
hadìth android yang telah mereka buat dengan judul 40 Hadis Mudah Dihafal, sebagaimana berikut:

Menjadi pertanyaan banyak orang, kenapa para ulama banyak yang menulis Arbaîn, bahkan dalam catatan penulis, tidak kurang dari 350 Arba'in yang sudah ditulis ulama. Barangkali apa yang disebutkan oleh Imam al-Nawawi dalam Arba'inn-nya, menjadi sandaran dan dasar yang sama yang dilakukan oleh para ulama. Bahkan, di akhir mukaddimahnya, beliau menjelaskan bahwa salah satu sebab beliau ikut menulis kitab Arbain adalah karena mengikuti tradisi ulama-ulama yang sholeh yang sudah lebih dahulu melakukan hal yang positif ini. Selain apa yang sudah disampaikan oleh Imam al-Nawawi, hemat penulis, ada beberapa faktor lain, yaitu: dapat menjadi bacaan awal bagi para pemula, mudah dihafal, dapat dijadikan standar dasar yang cukup simpel buat satu tema, dan bagi ulama pun, menjadi sangat mudah untuk mengarangnya. ${ }^{32}$

Alasan yang bersumber dari apa yang telah dikemukakan oleh kalangan ulama hadīth di masa yang telah lalu turut diaminkan dan dikutip oleh pihak PKH, sebagai alasan mereka dalam memilih tema hadīth Arbain terhadap pembuatan produk-produknya.

Keempat, visualisasi hadìth. Dalam hal ini, PKH melakukan visualisasi ḥadīth baik berbentuk audiovisual seperti kajian hạaīth yang ditayangkan di channel YouTube maupun melalui live streaming di Halaman (Page) Facebook milik PKH sendiri, serta visualisasi hadīth dalam bentuk meme yang biasanya diposting melalui akun Instagram dan Fecebook PKH.

Gambar 11:

Channel YouTube dan Akun Instagram PKH

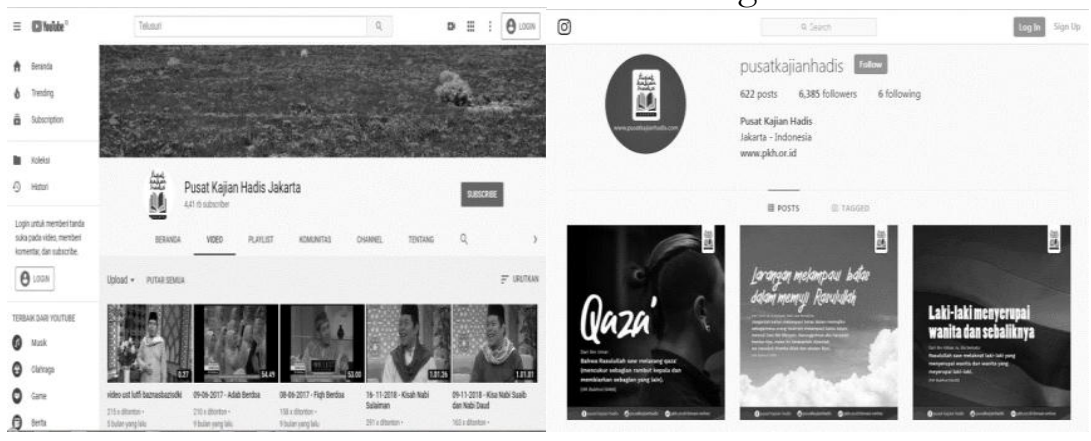

32 Ahmad Lutfi Fathullah, 40 Hadis Mudah di Hafal, aplikasi android, diakses pada 5 Desember 2019. 
Gambar 12:

Tampilan Halaman Facebook PKH

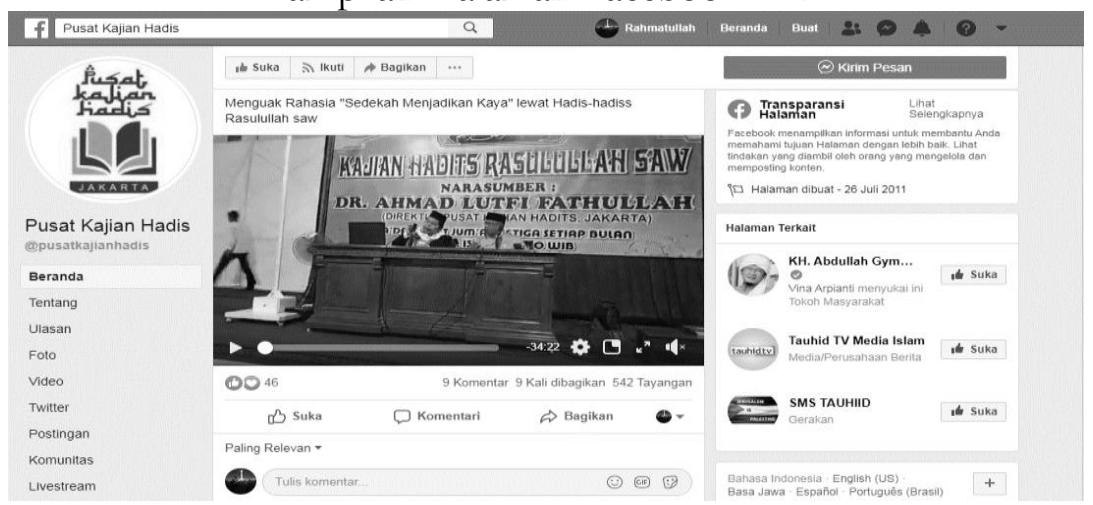

\section{Implikasi Digitalisasi terhadap Transformasi Kajian Hadīth}

1. Statis

Pada tingkatan tertentu, upaya digitalisasi hadīth membawa, salah satunya, implikasi statis terhadap tradisi kajian hadīth. Hal ini setidaknya dapat dilihat dari pemanfaatan keberadaan kitab hadīth versi cetakan yang kini perannya sudah mulai tergeser; peran kitab hadìth versi cetak dalam situasi terkini sudah cenderung tidak diminati lagi akibat adanya pergeseran orientasi tradisi kajian hadīth yang kini lebih menaruh perhatian pada kajian yang bersifat digital. Dalam konteks hari ini, fenomena di atas terutama terasa dengan grafik tingkat konsumsi terhadap kitab ḥadīth versi cetak yang menurun. Eksistensi media digital, dengan demikian, pada tingkatan tertentu menjadi ancaman bagi keberadaan media cetak. ${ }^{33}$

Transmisi keilmuan hadīth pun secara fundamental mengalami kedaan statis. Dalam hal ini, digitalisasi hadìth telah berdampak pada statisnya tradisi lisan (hafalan) maupun tulisan. Selain memberikan kemudahan bagi masyarakat dalam kajian hadīth, upaya digitalisasi hadīth rupanya juga telah meniscayakan terkikisnya tradisi kajian hadīth secara lisan (hafalan) maupun tulisan yang begitu kuat pada masa-masa sebelumnya. Terkikisnya tradisi tersebut diakibatkan oleh kemudahan masyarakat dalam mengakses, memperoleh, maupun mengkaji hadīth melalui media

\footnotetext{
${ }^{33}$ Satria Kusuma, "Posisi Media Cetak di Tengah Perkembangan Media Online di Indonesia", Jurnal InterAct, Vol. 5, No. 1 (2016); Andrey Andoko, "Teknologi Digital: Akankah Media Cetak Berakhir?”, Jurnal Ultimatics, Vol. 2, No. 1 (2010).
} 
digital. Tradisi kajian yang bersifat tradisional dan pernah berlangsung di masa yang telah lalu kini secara pelan-pelan telah berhenti.

Hal senada juga terjadi dalam tradisi akademik dunia pendidikan. Tidak kegiatan pembelajaran yang mulai kurang melakukan kajian hadìth secara tradisional, seperti pemanfaatan kitab hadīth versi cetak, atau kegiatan menghafal dan menulis hadìth. Para akademisi kini telah dimanjakan dengan keberadaan dan pemanfaatan software dalam mengkaji hadīth. Pemanfaatan software Maktabah Syamilah dan Jawämi al-Kalim di banyak Perguruan Tinggi Agama Islam dalam rangka penelusuran hadīth atau kajian takhrij hadīth merupakan contoh terbaik dalam konteks ini. Tradisi kajian hadìth yang bersifat tradisional kini sudah mulai layu atau telah dikesampingkan, dan beralih pada pola kajian hadīth yang lebih modern dengan basis digital yang simpel, efisien, dan lebih menarik.

2. Dinamis

Upaya digitalisasi hadīth telah membawa implikasi transformasi yang dinilai dinamis berupa adanya pergerakan atau penyesuaian kajian hadìth dengan spirit era yang sedang berlangsung, dalam hal ini adalah era digital. Dinamis dalam hal ini berarti penuh semangat dan tenaga sehingga cepat bergerak dan mudah menyesuaikan diri dengan keadaan dan sebagainya; mengandung dinamika. Tradisi kajian hadīth yang mulanya bersifat tradisional kini telah mendapat angin segar dengan adanya digitalisasi hadith yang tidak bisa tidak memberikan implikasi bagi dinamika perkembangan kajian hadīth. Proyek digitalisasi hadīth berupa software, aplikasi android, dan visualisasi hadith telah memberikan efek positif terhadap kajian hadìth, baik yang bersifat formal maupun non-formal.

Dinamika kajian hadīth di era kontemprer terutama terlihat pada sisi pemanfaatan teknologi digital, seperti yang ditunjukkan oleh beberapa situs web seperti Islamweb.net, Carilahhadis.com, Dorar.net, Perpustakaanislamdigital.com, dan lain sebagainya. Produksi dan pemanfaatan software hadìth seperti Lidwa Pusaka, Maktabah Syamilah, Jawāmi' al-Kalìm, dan sejenisnya juga merupakan bagian dari dinamikan kajian hadīth era kontemporer. Demikin pula, aplikasi android juga turut ikut hadir dalam memenuhi kebutuhan para pengkaji hadīth yang pemanfaatannya dapat 
diaplikasikan secara praktis melalui handphone atau smartphone. Salah satu contoh aplikasi hadīth pada android yang dimaksud adalah Ensiklopedi Hadits-Kitab 9 Imam, dan beragam aplikasi hadith lainnya yang dapat dengan mudah ditelusuri dan diperoleh lewat aplikasi Play Store yang sudah terpasang di setiap media seluler berbasis android.

Selain itu, implikasi dari digitalisasi hadìth juga dapat dilihat dari kontribusinya terhadap ragam kajian akademik hadīth kini, terutama hubungannya dengan media digital, yang kini bermunculan dengan ragam perspektif. Di antara beerapa kajian yang dimaksud adalah takhrij hadīth melalui aplikasi atau software yang dilakukan oleh Zulkipli et al. ${ }^{34}$ kajian aplikasi hadīth dengan nama "Seratus Satu Hadis" oleh Silviadi et al; ${ }^{35}$ kajian atas aplikasi hadīth "Masuk Surga" karya Ahmad Lutfi Fathullah yang dilakukan oleh Fahrudin ${ }^{36}$ kajian hadìth dengan objek yang sedikit berbeda, yaitu mengenai orientasi kajian hadìth di Indonesia lewat penelusuran atas artikel digital yang berada dalam portal morarf, oleh Huda et al., ${ }^{37}$ hingga menyentuh pada kajian hadīth dan visualisasi yang kini sudah mulai ramai dilakukan dengan salah satu objeknya yaitu komik hadīth. ${ }^{38}$

\footnotetext{
34 Shahril Nizam Zulkipli et al., "Takhrij Al-Hadith via Mobile Apps: Study of 9 Imam Encyclopedia, Kutub Tis'ah and Mawsu'ah al-Hadith al-Nabawi alSyarif', International Journal of Academic Research in Business and Social Sciences, Vol. 7, No. 6 (2017).

${ }^{35}$ Diki Silviadi et al., "Pengembangan Aplikasi Seratus Satu Hadis tentang Budi Luhur Berbasis Multimedia", Jurnal Algoritma, Vol. 13, No. 1 (2016).

${ }^{36}$ Fahrudin, "Kajian Hadis Era Android (Telaah Aplikasi 'Masuk Surga' Karya Ahmad Lutfi Fathullah)”, Diroyah: Jurnal Ilmu Hadis, Vol. 4, No. 1 (2019).

37 Nailil Huda dan Ade Pahrudin, "Orientasi Kajian Hadis Kontemporer Indonesia (Studi Artikel E-Jurnal dalam Portal Moraref 2015-2017)”, Refleksi, Vol. 17, No. 2 (2018).

${ }^{38}$ M Syaifurriza Nuris dan Aditya Rahman Yani, "Komik Hadits Pokok Ajaran Islam", Createvitas, Vol. 3, No. 1 (2014), 14; Suryadilaga, "Syarah Hadis Sahih Bukhari dan Muslim dalam Komik: Studi atas Deskripsi 99 Pesan Nabi: Komik Hadis Bukhari Muslim (Edisi Lengkap)", Esensia: Jurnal Ilmu-Ilmu Ushuluddin, Vol. 16, No. 2 (2015), 153-168; Miski, "Komikisasi Hadis: Arah Baru Syarah Hadis di Indonesia Studi Kritis atas 99 Pesan Nabi: Komik Hadis BukhariMuslim", Millati: Journal of Islamic Studies and Humanities, Vol. 2, No. 1 (2017), 125-144; Suryadilaga, "Komik Hadis Nasihat Perempuan: Pemahaman Informatif dan Performatif”, Jurnal Living Hadis, Vol. 2, No. 2 (2018), 209-252.
} 


\section{Statis-Dinamis}

Adapun implikasi yang bersifat statis sekaligus dinamis dalam kajian hadīth dapat dilihat melalui platform Perpustakaan Islam Digital (PID) yang merupakan salah satu produk PKH. PID merupakan platform yang menghimpun berbagai macam kitab terkait kajian keislaman (Islamic studies), yang sementara ini telah menghimpun 6.100 jilid kitab dengan 2.770 judul. Salah satunya adalah kitab hadīth dengan jumlah 2.066 jilid yang terdiri dari tiga bagian, yakni ilmu hadìth (sebanyak 135), rijäl al-ḥadith (258), dan matn al-hadith (1.673). Literatur hadìth merupakan literatur yang paling mendominasi jumlah koleksi digital PID. Kapasitas PID yang terbilang presitius tersebut tak bisa dilepaskan dari misinya untuk menyempurnakan kekurangan-kekurangan platform digital hadīth lain yang telah ada sebelumnya, seperti Maktabah Syamilah, Mawsü'at Hadith al-Sharif, Jawāmi' al-Kalim, dan Waqfeya.com.

Sebagai sebuah perpustakaan digital dengan basis literatur kajian ke-Islaman, PID dapat dikatakan sebagai wadah kolaborasi bagi kajian hadith yang bersifat statis sekaligus dinamis. Implikasi statis dalam hal ini ditunjukkan oleh informasi maupun lietaratur hadìth yang menjadi konten dalam platform ini tetap fokus menyediakan literatur-literatur hadīth tanpa mengubah formatnya atau sesuai wujud kitab hadīth versi cetaknya. Format interaksinya pun sama persis ketika berinteraksi langsung dengan kitab versi cetaknya (flipbook). Bagi kalangan yang merasa tidak nyaman dengan fasilitas tersebut, format pdf bisa menjadi opsi yang tepat. Perlu ditegaskan bahwa ini bukan platform yang dapat digunakan untuk men-takhrij hadìth atau menyediakan fasilitas pencarian hadīth menurut kata atau tema. Platform ini hanya berfungsi sebagai wadah untuk menampung kitab hadith dan mengklasifikasikannya sehingga fasilitas yang disediakan pun hanya sebatas pencarian terhadap kitab hadīth yang ingin digunakan. Pada titik ini lahplatform ini menunjukkan implikasi statisnya. 
Gambar 13:

Tampilan Koleksi Digital PID

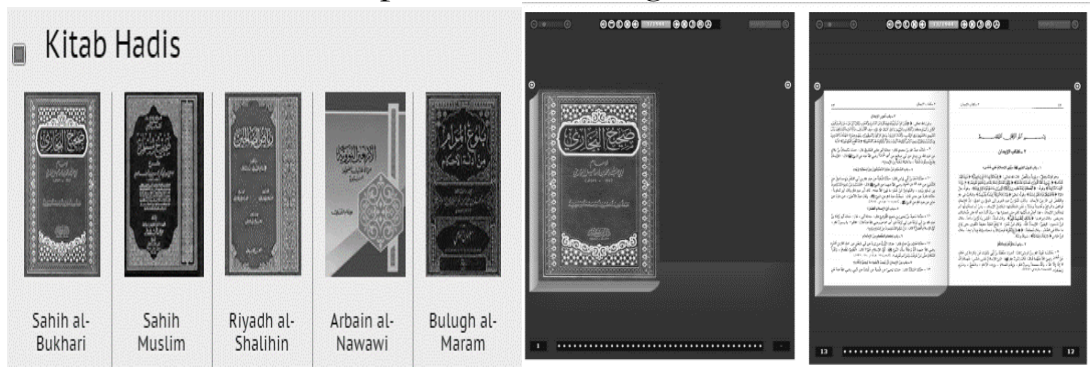

Sementara itu, implikasi dinamis dari platform ini menunjuk pada eksistensi platform ini yang setidaknya sudah menjadi salah satu wadah representatif bagi kitab-kitab hadīth yang sudah didigitalkan. Keberadaan literatur hadīth memunculkan penilaian bahwa eksistensi kajian hadīth kini telah mulai merambah bergerak dan berkembang sesuai spirit kekinian, yaitu salah satunya adalah degan pemanfaatan teknologi digital. Sisi dinamis dari platform ini pun akan terus berlanjut melalui program pengembangan yang dirangcang oleh PKH yang tanpa henti menambah koleksi kitab digital yang juga telah dialihbahasakan (dalam hal ini dari bahasa Arab ke bahasa Indonesia).

\section{Penutup}

Perkembangan digitalisasi hadīth di Indonesia tebilang dinamis. Hal tersebut dapat dilihat dari beragamnya bentuk digitalisasi hadìth, seperti software, situs web, literatur versi digital, aplikasi hadìth, dan visualisasi hadīth. Urgensi digitalisasi hadīth dapat didasarkan pada beberapa faktor, seperti keniscayaan perkembangan zaman digital; tingginya minat serta perhatian generasi milenial untuk mengonsumsi segala hal melalui media digital; dan keharusan untuk mempertahankan eksistensi tradisi kajian hadīth. Upaya digitaliasi hadīth di Indonesia dipelopori oleh, salah satunya yang terpeting, Fathullah melalui lembaga PKH yang dibangunnya. Ragam produk digitalisasi hadīth yang dihasilkan oleh PKH kini telah memberikan implikasi yang cukup signifikan dalam hal transformasi tradisi kajian hadìth; kini kajian hadìth, lebih-lebih dalam konteks Indonesia, menjadi lebih baru dan segar. Berdasarkan kenyaan ini, kehadiran digitalisasi hadìth tampak menjadikan masa depan kajian hadìth kian cerah dan dinamis. 


\section{Daftar Rujukan}

Ahmad, Nur. "Tantangan Dakwah di Era Teknologi dan Informasi: Formulasi Karakteristik, Popularitas, dan Materi di Jalan Dakwah”, Addin, Vol. 8, No. 2, 2014.

Alfinnas, Shulhan. "Arah Baru Pendidikan Islam di Era Digital", Fikrotuna: Jurnal Pendidikan dan Manajemen Islam, Vol. 7, No. 1, 2018.

Andoko, Andrey. "Teknologi Digital: Akankah Media Cetak Berakhir?”, Jurnal Ultimatics, Vol. 2, No. 1, 2010.

Basharat, Amna et al. "Semantic Hadith: Leveraging Linked Data Opportunities for Islamic Knowledge". Makalah pada konferensi Linked Data on the Web (LDOW), Montreal, Kanada (2016).

Budiantoro, Wahyu. "Dakwah di Era Digital", Komunika: Jurnal Dakwah dan Komunikasi, Vol. 11, No. 2, 2018.

Fahrudin. "Kajian Hadis Era Android (Telaah Aplikasi 'Masuk Surga' Karya Ahmad Lutfi Fathullah)", Diroyah: Jurnal Ilmu Hadis, Vol. 4, No. 1, 2019.

Fathullah, Ahmad Lutfi. 40 Hadis Mudah di Hafal. Aplikasi android, diakses pada 5 Desember 2019.

Ghafur, Waryono Abdul. "Dakwah Bil-Hikmah di Era Informasi dan Globalisasi: Berdakwah di Masyarakat Baru", Jurnal Ilmu Dakwah, Vol. 34, No. 2, 2014.

Halim, Amran Abdul et al. "Popularity of Digital Hadith

Application (DHA) in Malaysia", International Journal of Civil Engineering and Technology, Vol. 9 (2018).

http://warungustad.com/pengantar/. Diakses pada 5 Desember 2019.

https://pkh.or.id., “Tentang PKH”. Diakses pada 5 Desember 2019.

https://pkh.or.id/tentang-kami/program-kerja-pkh/. Diakses 5 Desember 2019.

Huda Nailil, dan Ade Pahrudin. "Orientasi Kajian Hadis Kontemporer Indonesia (Studi Artikel E-Jurnal dalam Portal Moraref 2015-2017)", Refleksi, Vol. 17, No. 2, 2018.

Istianah dan Sri Wahyuningsih. "The Hadith Digitization in Millennial Era: A Study at Center for Hadith Studies, Indonesia", QIJIS, Vol. 7, No. 1, 2019. 
Khațīb (al), Muhammad 'Ajaj. Al-Sunnah Qabl al-Tadwinn (Beirut: Dār al-Fikr, 1981).

Kusuma, Satria. "Posisi Media Cetak di Tengah Perkembangan Media Online di Indonesia", Jurnal InterAct, Vol. 5, No. 1, 2016.

Luthfi, Emha et al., "Digital hadith authentication: A literature review and analysis", Journal of Theoretical and Applied Information Technology, Vol. 96, No. 15 (2018).

Maulana, Luthfi. "Periodesasi Perkembangan Studi Hadits (Dari Tradisi Lisan/Tulisan hingga Berbasis Digital)", Esensia: Jurnal Ilmu-Imu Ushuluddin, Vol. 17, No. 1 (2016).

Miski. "Komikisasi Hadis: Arah Baru Syarah Hadis di Indonesia Studi Kritis atas 99 Pesan Nabi: Komik Hadis BukhariMuslim", Millati: Journal of Islamic Studies and Humanities, Vol. 2, No. 1, 2017.

Mudin, Miski. Islam Virtual: Diskursus Hadis, Otoritas, dan Dinamika Keberislaman di Media Sosial. Yogyakarta: Bildung, 2019.

Muhajirin. "Melacak Akar Pembelajaran Hadis di Nusantara", Holistic Al-Hadis: Jurnal Studi Hadis, Keindonesiaan, dan Integarasi Keilmuan, Vol. 1, No. 1 (2015).

Muhasim. "Pengaruh Tehnologi Digital terhadap Motivasi Belajar Peserta Didik", Palapa: Jurnal Studi Keislaman dan Ilmu Pendidikan, Vol. 5, No. 2, 2017.

Munir. Pembelajaran Digital. Bandung: CV. Alfabeta, 2017.

Nayshābūrī (al), Abū Hasan Muslim b. al-Hujjāi al-Qushayrī. Sahīị Muslim, Vol. 4, Tahqīq: Muhammad Fu'ād 'Abd al-Bāqī. Beirut: Dār al-Ihyā̄' al-Turāth al-'Arabī, t.th.

Nur'aini, Alfi. "Metodologi Interpretasi Hadis Ahmad Lutfi Fathullah dalam Kajian Kitab Kuning Shahih Bukhari (Studi Terhadap Interpretasi Audio Visual)". Tesis--UIN Sunan Kalijaga Yogyakarta, 2018.

Nuris, M Syaifurriza dan Aditya Rahman Yani. "Komik Hadits Pokok Ajaran Islam", Createvitas, Vol. 3, No. 1, 2014.

Rahman, Mujibur. "Visualisasi Agama di Ruang Publik: Komodifikasi, Reproduksi Simbol dan Maknanya", Humanistika: Jurnal Keislaman, Vol. 4, No. 1, 2018.

Setiawan, Wawan. "Era Digital dan Tantangannya". Makalah pada Seminar Pendidikan Nasional, Universitas Pendidikan Indonesia (2017), 1-2. 
Sijistānī (al), Sulaymān b. al-Asy'as b. Ishạāq b. Bishr b. Shidād b. Amr al-Azdī. Sunan Abì Dāwùd, Vol. 4, Taḥīq: Muḥammad Muhy al-Dīn 'Abd al-Hamīd. Beirut: Maktabah al-'Așrīyah, t.th. Silviadi, Diki et al. "Pengembangan Aplikasi Seratus Satu Hadis tentang Budi Luhur Berbasis Multimedia", Jurnal Algoritma, Vol. 13, No. 1, 2016.

Suryadilaga, Muhammaad Alfatih. "Syarah Hadis Sahih Bukhari dan Muslim dalam Komik: Studi atas Deskripsi 99 Pesan Nabi: Komik Hadis Bukhari Muslim (Edisi Lengkap)", Esensia: Jurnal Ilmu-Imu Ushuluddin, Vol. 16, No. 2, 2015.

-----. "Kajian Hadis di Era Global", Esensia: Jurnal Ilmu-ilmu Ushuluddin, Vol. 15, No. 2 (2014).

-----. "Komik Hadis Nasihat Perempuan: Pemahaman Informatif dan Performatif”, Jurnal Living Hadis, Vol. 2, No. 2, 2018.

Ummah, Siti Syamsiyatul. "Digitalisasi Hadis (Studi Hadis di Era Digital)", Diroyah: Jurnal Ilmu Hadis, Vol. 4, No. 1 (2019).

Zulkipli, Shahril Nizam et al. "Takhrij Al-Hadith via Mobile Apps: Study of 9 Imam Encyclopedia, Kutub Tis'ah and Mawsu'ah al-Hadith al-Nabawi al-Syarif', International Journal of Academic Research in Business and Social Sciences, Vol. 7, No. 6, 2017. 